\title{
The Jurisdiction of "Larvul Ngabal" as a Mediation of Land Disputes in Kei Islands
}

\author{
Bumi Ayu ${ }^{1}$ Mella Ismelina Farma Rahayu ${ }^{1 *}$ \\ ${ }^{1}$ Faculty of Law, Universitas Tarumanagara, West Jakarta 11440, Indonesia \\ *Corresponding author. Email: mellaismelina@fh.untar.ac.id
}

\begin{abstract}
The values in the customary law of "Larvul Ngabal" consists of 7 articles and divided in to 3 groups. "Nevnev" law is part of articles 1 to article 4, which regulates human life. "Hanilit" law consists of articles 5 and 6 , and regulates about morals, while "Hawear Balwirin" law regulates rights and social justice in article 7. This study was conducted in the Kei Islands, Southeast Maluku, Legal research method used is descriptive empirical analysis of approaches to conducting research based on field observations and interviews. Data were analyzed by a qualitative method. This study provided a detailed situation of land disputes towards the customary law of "Larvul Ngabal" in Kei Islands, Southeast Maluku. This study aims to evaluate the land disputes through customary land courts, especially the effectiveness of customary law in resolving land disputes in the Kei Islands. Customary judges' decisions are recognized by the customary law community and regulations. Therefore, every decision by a customary judge must be concerned; however, court decisions have more legal force than customary court decisions. The benefits of customary court decisions need short time and save costs for dispute resolution, especially in the land sector through customary law. There is mediation through the customary land court. This problem always resolve with a repressive approach. It reveals that dispute process must be resolved through the courts. Dispute resolution is conducted through deliberation. Family mediation along with customary justice institutions consists of Soa, Orang Kay, Tuan Tan, Mitu Duan, Hukum Duan, Marin, Wak-wak. After the mediation process takes place in peace, then Hawear (prohibition sign) revoked by the Father King through customary procession. Implementation of customary law is still conducted these days by indigenous and tribal people in Kei Islands, Southeast Maluku because it is considered effective in resolving land disputes. The approach to resolve land disputes through customary courts is a form of state recognition and respect for indigenous peoples and their traditional rights as long as they are still alive and in accordance with community development and the principles of the Republic of Indonesia. Judging from the norms governing the judiciary in Indonesia, traditional courts are not well known, but according to Article 25 paragraph (1) of the Law on Judicial Powers, it is possible to make it a special court or at least an ad-hoc court.
\end{abstract}

\section{Keywords: Customary court, land dispute}

\section{INTRODUCTION}

Every country is struggling or carrying out sustainable development to improve people's welfare. Every development, of course needs natural and human resources Philosophical foundation of environmental development law in Indonesia must give back the opportunity of various relationship formations as a form of creation of better ecological life, namely the relationship between God, Humans, and Environmental Life. Developing a philosophical foundation environmental development law based on local wisdom/culture of religion, social movements and empowerment is absolute. Larvul Ngabal Law is a legal customary law that applies in regulating the lives of indigenous and tribal people in Southeast Maluku, which consists of 2 types namely Ratschaap (community unity customary law that is formed based on history and origin) and Ohoi/village (customary law community unit that is based on territorial genealogy, possessing borderline). United community in Southeast Maluku is divided into 3 customary law community groups namely Ur Siuw (9 Ratschaap), Lor Lim (5 Ratschaap) and Lor Lobai (2 Ratschaap) in Southeast Maluku which are recognized hereditarily for generations, become a living law, continue being developed and maintained.

Larvul Ngabal Law applies in the entire Kei Island region, consists of 7 Articles namely: Nevnev Law (the law that regulates the rights of human life). Article 1 Uud enthuk atvunad (Head rests on shoulders, which means: As a leader you have to always being integrated with people, feel the ups and downs of the community and being integrated in every motions and dynamics of the community. Community/children are always aware of themselves as inseparable part with the leader that they can give support 
and ready to take orders related to progress and mutual benefit. Article 2 Lelad ain fo mahiling (Neck and human safety must be upheld), which means: Do not hurt/cut let alone kill because life is truly glorious. Then it must be respected. This article is very respectful towards humanity. Article 3 Ul nit envil atumud (Skin wraps our body), which means: Prohibit defaming act. Article 4 Lar nakmot ivud (blood circulating calmly inside the body), which means: Do not act arbitrarily towards others that cause injury or bloodshed let alone for murder to happen. Hanilit Law (the right of honor and the dignity of women). Article 5 Rek fo mahiling (Threshold for ash or the sanctity of women is exalted), which means: Room limit must be respected. Article 6 Moryaian fo kelmutun (Chastity of the household is upheld high), which means: A bed of people who are already married must be glorified, it is not permitted for men to enter the room of a woman who is not his wife. This Article upholds the dignity of women. Hawear Balwirin Law (law which regulates property rights). Article 7 Hira ni fo $i$ ni, it did fo it did (Other people's belongings remain theirs and ours remain ours), which means: Other people's belongings belong to them, ours are still ours. This article quite clearly regulates property rights of people that should not be disturbed and betrayed. Do not be greedy for something that is not ours that can lead to cheating, and justice towards others. If the rights belong together and must be evenly divided so that principles of justice must be upheld. Ownership that becomes right is what will be protected by the Hawear Balwirin Law. Hawear Balwirin Law is a rule based on the principle of preservation and balance of nature's relationship with human, maintain and guarantee the existence of recognition of the human rights their life, and give assessment and appreciation for the land so that it becomes a special object and gets special treatment in its settings. The principle is rooted from philosophy: itdok fo Ohoi itmian fo nuhu, which means we inhabit the country or village where we live and eat from nature / its land. Examples of sanctions according to Larvul Ngabal customary law as follows: Nevnev Law (Murder), form of violation Fedan Na/Tetat Vanga (killing someone), form of sanctions: pay 40 fathoms consists of 1 piece of gong as head replacement, 1 piece of lela as the replacement for Tetan Lurin (spine), 1 piece of Reu Rad gold as a replacement for the navel string, 3 pieces of tahil tulen gold as a replacement of Vuan Yatan and some money for other body parts and to restore human. Hanilit Law (Decency), forms of violation: Dos Ur War, Ten Yanat (impregnating siblings, biological child or niece), form of sanctions: The same as sanctions of killing people (Nevnev Law) namely Luduk Na'a Nile Nuhutel (drowned) and family expelled / condemned for life. Hawear Balwirin Law, form of violation: It Lavur Hera Ni Afa (Damaging private / public property). Like Roa Nangan, Met Tahit that is already given Hawear (prohibited sign), form of sanctions: pay 1 piece of lela/ancient cannon as a fine violating Hawear (prohibited sign); and tahil tulen gold or a number of property (money, valuables) for customary elders according to customary congregation.

\subsection{Our Contribution}

This research is expected to provide input for stakeholders such as academics, law enforcement officials, and the government in the framework of preparing and perfecting legal instruments and policies pursued for efforts to strengthen the rules for resolving land disputes through customary land courts in Indonesia in particular. Kei Islands, as well as the results of this research will be useful to provide legal protection, legal certainty and provide a sense of justice for the community and / or government.

\subsection{Paper Structure}

The rest of the paper is organized as follows. Section 2 introduces the preliminaries used in this paper, which include how is the existence of customary law in Kei Islands, Southeast Maluku and how is the process of land disputes through customary courts in Indonesia.

\section{BACKGROUND}

Based on the Agrarian law, there is an eternal relationship between the Indonesian nation and land, as stated in Article 1 paragraph (3) of the Law of the Republic of Indonesia Number 5 of 1960 concerning Basic Agrarian Regulations. However, the land issue is a major problem in Indonesia and has not regulated with a proper regulation. There are many various deregulation and policies in the land sector to provide the era of free trade in empirical terms. The emergence of various land cases cannot be separated from government policies which are mostly ad-hoc, inconsistent, and ambivalent. The structure of land law overlaps with the Basic Agrarian Law Number 5 in 1960. It is substantially conflicted with the various sectoral laws and regulations. Sectoral laws have a similar position and make the lands as a similar object. Therefore, conflicts cannot be avoided by the different sectoral government. The differences between these laws can provide opportunities for differences in the interpretations of bureaucrats and the laws are not substantially integrated.

Furthermore, it cannot be denied from a juridical perspective. Solving land problems is not a simple case. It often involves several agencies related to problems in the general courts and administrative courts.

Land dispute resolution through court institutions is not effective because it takes a lot of time and costs. There is a potential for third party interference with certain motives that affects court decisions. Even among the public, there have been widespread rumours that the Supreme Court does not quickly provide a solution. This condition increases the public doubts about the effectiveness of dispute resolution. Therefore, land dispute resolution is urgently needed to support a conducive acceleration and provide more legal assurance. Moreover, it should provide certainty and satisfaction for people. There is mediation through the customary land court.

Deliberation is a common method to reach consensus in Indonesia. Therefore, land cases are not involved in the 
administrative and criminal aspects, as long as they held a mediation method. It is regulated in Article 14 of Law of the Republic of Indonesia Number 5 of 1960 concerning Basic Agrarian Regulations. concerning basic judicial power provisions to settle civil cases peacefully. The people in the Kei Islands have a customary law system called the Larvul Ngabal customary law. This regulation maintenance customary governance starting from a combination of several Ohoi (villages). There are two types of leadership models in the Kei Islands. First, a formal leader is a state government and recognized by the community as a major factor in developing various fields. Second, the informal leader is a customary government to support a formal leader. The customary law of Larvul Ngabal as a hereditary legacy. People in Kei islands obey this law until now. Moreover, it can be further understood as a step forward in social harmony in people's lives.

\section{METHODS}

Applicable regulations and legal theories were used in this study. They were concerned against the problem of land dispute resolution through customary land courts in the Kei Islands. The sociological juridical method was used in this study. Moreover, primary data were obtained by observations and interviews of the Kei indigenous peoples. The Constitution of the Republic of Indonesia in 1945, the Basic Agrarian Law, regional regulations, national journals, international journals, and legal dictionaries were used as secondary data.

\section{FINDINGS AND DISCUSSIONS}

Land tenure management system of Kei indigenous people In people's lives in Maluku Islands generally and especially the legal customary community alliance in Southeast Maluku, there are 3 forms of land tenure namely land can jointly be owned by ohoi / village together, klen or clan group, and family in private. Land tenure is set based on inheritance system. Land property for the Kei indigenous people is as inheritance. Then its use is also arranged according to the system of inheritance, that is patrilineal. In the patrilineal system, the one who is entitled to receive inheritance is the men from the male lineage and the eldest. Except when there is no male descendant, then the owner of property right is the women if there is a gift / award from the testator, this term by the Kei indigenous people is called "Bayo Venven Ve Renar Urar." There are authority limitations in use her rights because in terms of releasing part or all ownership to other party permanently (definitive) is not feasible or fitting for women. Because of the heritage tradition factor and symbolic views of women and land together are the source / origin of life. Then attitudes towards the land is the same with attitudes towards women. The Kei indigenous people have the view that land property, is one of the very important legacies and as a source of live/can be managed. However, the application is implemented according to the value system (gender) and order of law norms. The management system is carried out on the basis of system of values and norms, such as togetherness, the law of harmony, sustainability and sustainability. Kei indigenous people recognize property right and use right in accordance with their philosophy of life: "ain ni ain, hira ni fo I ni, itdid fo itdid, tadok nn did kovat ne tafif non did bamiir, kes u yang mur."

The ownership of land and sea in the Kei Islands basically have been divided to all citizens community in regional units. To ensure landownership, can be seen from the will, poetry or songs spoken by ancestors. It can also be seen from the physical evidence that is still standing like woma (village center), which is a place that is surrounded by walls made of piles of stones. Usually the first clan that settled somewhere would establish woma (village center) in a difficult to reach place to be effective as a defensive place from enemy attacks or wild animals. Land property boundaries usually are in the forms of peaks/foothills, valleys, big stones, piles of stones, big trees or river flow.

Distribution of land and sea ownership to all Kei indigenous people in the property area unit is as follows:

1. Public Village/Kampong Property called utan / bilan / ohoinuhu, which is land area that belongs to all members of the community village / village concerned together. This territory includes the whole village is the same with the total of land area in the concerned village plus the sea area before it.

2. Clan property which is called rahan faam or buuk faam I area that is permanently owned by one clan (Soa) of village indigenous people that only covers land area. Likewise, the sea areas, all of them belong to public ownership of the village that is not allowed to be owned by one clan or privately.

3. Pati Family Property (riin nutun matan), that is land owned permanently by a household of concerned clan members.

Every development requires natural and human resources.[1] The foundation of environmental development law in Indonesia must provide an opportunity for various relationships to support a better ecological life. The relationship between God, humans, and the environment must be balanced each other. Developing a philosophical foundation of environmental laws is conducted based on local wisdom, religious culture, and social empowerment.[2] West Sumatra is also confronted with some conflicts related to land acquisition process which, unfortunately, has been resulting in a deadly clash between oil palm companies and indigenous people who want to take their customary land back because the land is not obtained in accordance with the customary law, principles and procedures or because local governments and companies do not fulfill the promises they made when they had a land agreement with indigenous people [3].

In dispute settlement especially regarding to ownership rights, Kei indigenous people carry out the implementation of custom restrictions which is called Hawear (Prohibition sign) which serves to guard civil rights, private property rights, group property rights, and community property rights (houses, land, land boundaries, natural environment especially marine and land products) and to reconcile 2 
people or 2 warring groups called with Hawear Nam Sait Ne Baran Nasor which means the sign of the ban is lifted and halved and an arrow was sent from the bow. Hereditarily, Hawear (prohibittion sign) consists of:

White shoots from a coconut tree (Nur Nar or Nur Vad Matlak). Wood which only be taken one kind, which is $\mathrm{Ai}$ Num, its characteristics: black bark, in yellowish wood, the sap water causes skin itching and is poisonous. 2 pieces of wood as toothed poles, 1 piece of horizontal wood and 1 piece of buffer wood. Red cloth (not random material) serves to bind coconut palm with Ai Num that then planted and installed so not just anyone can open or pull it out. Offering in the form of betel symbolizes purity/cleanliness, pinang palm and betel symbolize the ancestor's food habits, the Kei customary gold symbolizes assets owned, tobacco / cigarettes. Sarong symbolizes clothing for Hawear (prohibition sign) because it's considered to be the form of a woman without clothing. For the Kei indigenous people, Hawear (prohibited sign) on the Kei Islands literally means asking, like an older sister asking her younger sister about certain rights that she must get. Hawear (prohibition sign) is analogous to a woman who, if revoked without going through a customary procession is the same with striping a woman. This thing is considered very insulting and disrespecting the Kei custom. Therefore, Hawear (prohibition sign) that is revoked after the customary procession must be wrapped by cloth. Incense symbolizes the calling of the ancestor's spirit.

Forms of Hawear have the same weight, function and sanction, that is:

1. Leaves are cleaned, hung crosswise so that the strand falls downside.

2. Mounted upright, plaited a few strands on the coconut palm trunk, lined with stone.

Preparation for the Hawear (prohibition sign) installation ceremony as follows:

1. Starting from a meeting of the Customary Council to get agreement from all indigenous people regarding when it starts, enactment duration, and any punishment that will be charged to violators and various other technicalities.

2. If an agreement has been reached and determined, then matarumah (Clan Head) who traditionally tasked with preparing the prohibition signs. They are on duty to make and weave young coconut leaves as prohibition signs which will be anchored in the ceremony lace that had been predetermined (a certain place from local history). Matarumah (Clan Head) or other clans also prepare young coconut leaves for their own prohibition signs that they will weave at the ceremony place later after the main sign is mounted. All residents from children to grandparents, except who are unable, gather in that place.

The traditional ceremony and rite begin in the following order:

1. After the emcee invite those who are entitled to carry out the ceremony, then a selected elder takes 2 or 3 strands of young coconut leaves, enters the center of the ceremony place and starts doing waan (prayer to the
Creator to bless the Hawear installation this time and prevent it from failure due to causes: Matak am yot I, aubwarib mang er-mat te er-ot sa dos berkar teuluir rair suhut man fangriding yot $i$ ye na waen air I man watuk lauk. (Don't let a family member die or commit crime during Hawear (prohibited sign) installation ceremony, or experience severe pain that it can affect the Hawear (prohibited sign) installation ceremony the throwing of the first coconut leaf will throw off all kinds of havoc.

Matak am ot yot I, umat-ma bisa mafkanimunwat i bo ain raan gladenhov ain dem waid, ngoibenhaling raab enhaling ye naa waa en I man watuk lauk. (As humans, though we meet together to carry out a common purpose in this place, do not let there still be people present in this ceremony whose mouth said another while his heart said another, not as clean as this young coconut leaf, then this second young coconut leaf will limit and get rid of all possible evil like that).

Matak ambe nanangivoho te balreyaat amsak sisa ok ngarihi suban tai suban kaflaa ain enhov ain, ikna enhov walean te fakvu-nin ye naa waan en ni man wat lauk. (Do not let all present here, all leaders or the ones being led, maybe ever issued swear words or profanity to other people either openly or secretly, then the third young coconut leaf will limit and throw it away).

2. Ya avun kunnian na man uv hulak itdid nuhu met en hor people to-mat fo clean fo dit yot hawear i tuman betot. (Burn incense/frankincense and bring it around to all who is present which symbolizes that the whole village as well as the woven leaves used are stated clean and because it has lawful power).

3. Ya na ngu mas ye reet vev naang $u$ dan $i$ wanun ruk na it did numel kanimun fo bersih, itnartul nuhu met, membersih wuk umat tomat it fo Duad nit erfangan it enhov did yot $i$ mas enhov ngu $i$ ya na enhong hawear kidin mel enrat mamhormat duad enfang nan dadad yot $i$ fohok wusin enwar hasil berkat bok. Ya na ngu mas $i$ enhong hawear kidin balit ensu, man watul lauk afa sian sa bisa. (Scrape off a little gold from gold that has been prepared, then put in a coconut oil solution in a bowl, then pour a little coconut oil solution to the ground around the ceremony place as a sign to clean the village land and all human inhabitants please the ancestors and The Creator: then the elder holds the gold, coconut oil solution and the main Hawear (prohibition sign), pick it up from the right side of the main Hawear (prohibition sign) while saying a prayer while asking for His blessings upon this ceremony with the intention of getting good results. Then the elder lowered clutched gold and coconut oil solution from the left side of the main Hawear (prohibition sign) parent as a sign of getting rid of all weaknesses and crime.

4. Amtiv bib vauv hiv mamu I fo nakwi nak air yoa lauk vathair nail afa sian sa bisa ni laar ensu nuhu tanat niwang ihin umat a raan. (A goat/pig/chicken then is slaughtered at the ceremony place: screaming of the goat/pig/chicken when slaughtered is a sign of getting rid of all sins and wrongs, then the blood which is poured out on the Earth into parts of the ground, the cleaned feathers is the symbol of all mistakes of the villagers; 
while the meat is distributed to residents to eat and the bones become parts of other creatures (dogs, cats, ants, etc.) that are also entitled to get their share.

5. Finally, a person from matarumah (Clan Head) in charge of weaving the main Hawear (prohibition sign), carries the Hawear (prohibition sign) to the King/Village Chief by conveying words as follows:

Ya na u na hawear balwirin, teteen ubud nusid er ot of hukum nan batang hira i ni fo $i$ ni, it did fo it did, fa hokum tahat $i$ ensu hawear in fi $i$ wusin u leman man batang tut afa bisa, enhor ler $i$ na yot yutut nuur $i$. (I submit the Hawear (prohibition sign) that ancestors had set as law to protect, to keep so that ours remain ours, others' are still someone else's, to King Father so that the law that you hold is fused in Hawear (prohibition sign) so that it becomes strong to protect things starting from today the Hawear (prohibition sign) is declared.

6. King Father receives the main Hawear (prohibition sign) and announces as follows:

Leer i ya na u na hawear balwirin, tetetean ubun musid er ot of hukum enbatang hira $i$ ni fo $i$ ni, it did fo it did, na hukum Larvul Ngabal ni vatuh fit. Umat suksukat sangrahan naa Lor Siuw Lor Lim nuhu evav i, $i$ lek rek uum raut rat erwul tomat suksukat, naa Lor Siuw Formur, Sakmas, Baldu, Wahdad, Katel Elkel, Boirwaf Bohirir, naa Lor Lim Ibes, Bomor, Songli, Kirkes Tuvle, Yarbadang er ot er dad hukum fo mantabang it bisa i man hukum, hirarki enlaungli in ot sa $i$ ni hukum enwarngain ain sad sad man fo lo il hukum hawear $i$ enhov denda seeng (.....) rupiah turut ohoi ni putusan. Hira ki en fakleak reh rehee ma hira inkai dem waid i ni hukum helye. I naa roa roi ya yau ye $u$ na i. Binakil enfit. Il enfit naa roa roi man toek en hukum en na i na'a nangan wuk baba surat $i$ ded $i$ ded straat $i$, ya yau ye u na binakit enfit bahala enfit en hukum en na i. Ennra i nra nanganrai, ya yau ye u na binakil enfit, bahala enfit enteuk en hukum en na $i$. Hukum en $i$ ve en be enfakleak reh rehee ma hira enkai dem waid, leer enkai yok entevim busilek i ni ni hukum. Nuur hairi riin matan ain korat lai ngain tel, ina ina enhov fakleak: Ye yau ye u na hawear i leer we nuhu tanat duan tuan tan fo enfedir enhaai ensu lanat $i$ waun wuk enhai ensu mitun umat tomat it vuvur readratan fo it kai itwar non fo bok hukum i man batang it did fitroa fitnangan. Leer $i$ yot nuur na wai den i...... endir. (Today I planned the Hawear (prohibition sign) that ancestors had set as law to protect, to keep so that ours remain ours, others' are still someone else's which has been listed/stipulated in Larvul Ngabal law Article 7 which reads: "Hira I ni fo I ni, it did fo it did" (the property of others remains theirs, ours are still ours). The well-known humans at Lor Siuw and Lor Lim in the Kei Islands, namely the Bapa Raja, 12 people who are respected, at Lor Siuw is Fomur, Sakmas, Baldu, Wah'dad, Katel/Elkel, Boirwaf/Bohirir, and in Lor Lim is Ibes, Bomor, Songli, Kirkes, Tuvle, Yarbadang. These names are the names of the title of King (Customary Chief) in all customary territories in Kei Islands, both of the Lor Siuw and Lor Lim, the name Boirwat/Bo-hirir, for instance is the title name of Maur
Ohoiwut in the Lor Siuw customary territory King, has made and implemented these laws to look after us all and punish anyone who is guilty of violating them will be punished with the obligation to pay fine money. The amount of money is determined based on agreement of the Customary Council (Saniri Agency) meeting according to the decision from village meeting). Whoever is committing a violation furtively so it's not known by anyone, then that person will be punished as follows: if he goes out to sea, he will suffer from seven diseases and seven danger in the sea. On land, whether on the beach or near the beach, in the village as well as on the streets near the village, then there he too will be affected seven diseases and seven dangers that are there to punish them. In the forest, he will encounter seven diseases and seven danger there to pick him up. All penalties will apply to whoever breaks and mightily hides their mistakes so nobody knows, and if that happens then it fully becomes the burden of their own mistakes. Then now I (the King) give Hawear (prohibition sign) to the Land Lord (Property Chief) to be stuck to the forehead into the minds of all of us to keep remembering and keep the Hawear Balwirin law well.

7. Land Lord (Property Chief) then receives the Hawear (prohibition sign) the King and in a loud voice telling all residents present that the Hawear (prohibition sign) has been declared since that hour and day. After the Land Lord (Property Chief) stuck the Hawear (prohibition sign) in the determined place, the King shouted "Yo yo yo eeee ...... !!!" then followed by all residents present 3 times in a row. As a sign of sooth and well completion.

If the Hawear (prohibition sign) has been implanted on Soin wahan, tanat vat (land property boundary), Tahit met (seas and low tide), Ubut, kait (forest and former gardens), Ve'e yab (gardens), Meon amaran (plantations), Tet la vovan (pets), and Luv tav (heirlooms) then it has binding legal force. Therefore, a violator is imposed sanctions namely sanctions that are material or legal Delyoan law which is specifically for people who install Hawear (prohibition sign) in the context of protecting their property rights but if they do not manage to prove their ownership then the person concerned is liable to customary sanction to pay 1 piece of lela (ancient cannon) as a substitute for pole, and 3 tail Tel Mas (customary gold) as a substitute for coconut leaf, and Kevhuni legal sanctions, a kind of karmic law that isn't just applies to the parties involved, but also for all parties who are involved in the trial process. Because Kei people believe that all property right is based on lineage known as Hira ni fo i ni, it did fo it did (Others' remain theirs and ours remain ours).

Deliberation is not only in between indigenous leaders, but also family members and other local community members, and that the agreement must be made before the authorities [4]. Family mediation along with customary justice institutions consists of Soa acting as a customary leader as a judge of customary issues happened in the village he is accountable of, Orang Kay plays the role of village chief, Saniri plays the role of clan chief (rahan yam or faam) by 
carrying out the functions as a clan leader to settle disputes, marriage, inheritance, as well as liaison/intermediary in giving proposals/suggestions in scope of clan, Tuan Tan is responsible for the ins and outs of the boundaries of the village area, Mitu Duan plays the role of priest, becomes intermediary/liaison between humans and nature or ancestral spirits in the certain customary rite, Hukum Duan as intermediary with ancestors as enforcers of invisible law to bind or take things or cases off. Marin plays the role to deliver/announce the society about something or decision from the results of deliberations to the community, Wakwak acts as security by performing the limit-control function, the restriction limit that hereinafter reported to the village chief. After the mediation process takes place in peace, then Hawear (prohibition sign) revoked by the Father King through customary procession. Implementation of customary law is still conducted these days by indigenous and tribal people in Southeast Maluku because it is considered effective in resolving land disputes.

Settlement of disputes in Evu village, Kei Kecil sub-district in 2000 became the foundation of community life. It has been the government's target as a drinking water source in the Tual city, Southeast Maluku. The local government states that it is benefit to achieve the goals and sustainable development. Moreover, government promise to give compensation to the local community. But, government do not give compensation. Therefore, the community lost access to drinking water.

According to Raja Tual and Raja Dullah, all land and what is on it in the Kei Islands has been divided according to ancestors agreement since long ago when the customary law of Larwul Ngabal was enacted. Land owned by the community is Tuan Tan (earmarked) for the prosperity and welfare. The local community must approve the use of land in the Kei Islands for any purpose without exception. One of the cases is the exploitation of natural resources in the Kei Islands between the government and the community. This problem always resolve with a repressive approach. It reveals that dispute process must be resolved through the courts. The government and natural resource entrepreneurs often think that these disputes occurs due to misunderstandings between individuals or government employees. Compensation is not given an amount equal to the losses suffered by the community. Dispute resolution is conducted through deliberation. Therefore, there is absolutely no need for community response. Every decision is determined by unilaterally, whether it is appropriate or not worthy of a decision. It is measured based on the ability and ability of the government or company.

The peak of community resentment occurred in 2001. The community installed Hawear as Sasi sign of prohibition for anyone to use water source in Evu village. As a result, the government could not continue its business, and the surrounding community was under pressure from various parties. Sasi Hawear was maintained until a decision was made from the legal structure of the Evu community. The customary structure held deliberations for the entire community. Therefore, all local communities have the right to obtain and use clean water sources for residents' benefit and welfare.
Government efforts were conducted to persuade the local community against the decision of the customary structure. The government suggested sending an independent team and a pro-government team to resolve the case. The community only received directions to rethink the installation of sasi, but these efforts did not succeed for indigenous peoples in Evu village. The land must be used and maintained wisely the people in the Kei Islands. It seems to be unthinkable by the government as a form of recognition and respect for customary rights. What the local people do reflects the people in the Kei Islands who still hold firmly and are guided by the Larvul Ngabal customary law system. It is useful to protect the community. The vertical disputes between the government and the community show the strength and obedience of the community to its informal leaders. It must be recognized that customary law is powerful as a general rule in resolving disputes at the community level. It is due to they have their dispute resolution mechanism.

Increased complaints at the national land institute and lawsuits in the general court and state administrative court revolve around civil disputes regarding legal status. Besides, the concept of establishing a Land Court has been initiated by higher education people. Therefore, it is immediately formed to solve land disputes. The settlement of land disputes is regulated by government regulation number 10 in 2006. In addition, the Decree of the State Minister for Agrarian Affairs or Head of the National Land Agency Number 34 in 2007 has been issued by the Regulation of the Minister of Agrarian Affairs or Head of BPN Number 3 in 2011 are regulated for the settlement of land disputes and conflicts.

According to Bagir Manan, the practice of dispute resolution is a process of dispute resolution and takes time. It resolves various disputes by restoring brotherhood and friendship or called a win-win solution. It has been known as deliberation to reach a consensus, runggun adat, begundem, rembug desa (West Java), Karapatan Ninik Mamak (West Sumatra), Subak (Bali).

The customary law is recognized as part of the national legal system and law source based on Article 23 paragraph (1) of Law Number 14 in 1970 and amended by Law Number 35 in 1999. Furthermore, it is also regulated in Article 25 paragraph (1) of Law Number 4 in 2004, as an elaboration from the 1945 Constitution of the Republic of Indonesia and the amendment to Article 18B paragraph (2) Therefore, the value of customary law is firmly recognized as a basis for the National Land Law as stated in Article 3 and Article 6 of the Basic Agrarian Law Number 5 in 1960. Furthermore, deliberation for consensus is used as the basic method for land dispute resolution through mediation. It is regulated based on Law Number 30 in 1999 concerning Arbitration and Alternative Dispute Resolution.

The decisions of customary judges are not recognized explicitly. Moreover, customary judges' decisions are recognized by the customary law community and regulations. Therefore, every decision by a customary judge must be concerned; however, court decisions have more legal force than customary court decisions. The benefits of customary court decisions need short time and save costs 
for dispute resolution, especially in the land sector through customary law.

\section{CONCLUSIONS}

There were indigenous people of Balrayat Evav (the Kei tribe) who had the customary law of Larvul Ngabal in the Kei Islands. The customary law was used to protect civil rights or property rights for individuals, groups, or community property rights (houses, land, natural environment). The customary courts were state recognition and respect for indigenous people and their legal rights as long as they were alive and in accordance with community development and the principles of the Republic of Indonesia. Customary courts were not known, but it was associated with Article 25 paragraph (1) of the Law on Judicial Powers. It can be a particular court or at least an adhoc court.

\section{ACKNOWLEDGMENT}

This work was supported by Dispute Resolution Unit of Agrarian Office Southeast Maluku and customary law society in collecting and sharing the data on journal publication purposes.

\section{REFERENCES}

[1] Rahayu, MIF, AF. Susanto, LS Muliya. "ReligiousCosmic Based Philosophical Foundation of Environmental Development Law in Sundanese Local Wisdom." Central European Journal of International and Security Studies 12, no. 4, 2016, pp. 523-535.

[2] Rahayu, MIF. "Sustainable development in the perspective of Sundanese cultural wisdom." Journal of Engineering and Applied Sciences, 12 (18), 2017, pp. 4657-4660. DOI: https://doi.org/10.3923/jeasci.2017. 4657.4660

[3] Tegnan, H. 2015. "Legal pluralism and land administration in west Sumatra: The implementation of the regulations of both local and Nagari governments on communal land tenure." The Journal of Legal Pluralism and Unofficial Law 47: 1-12. DOI: https://doi.org/10. 1080/07329113.2015.1072386

[4] Hanifah, Mardalena, Ardiyanto, Syaifullah Yophi, and Tegnan, Hilaire. "Legislation to Reduce Land Conflicts in Indonesian Provinces.” Jan. 1, 2018, pp. 412 - 415. DOI: https://doi.org/10.3233/EPL-180109 